REPORTS OF MORPHOLOGY
$\begin{gathered}\text { Official Journal of the Scientific Society of Anatomists, } \\ \text { Histologists, Embryologists and Topographic Anatomists } \\ \text { of Ukraine } \\ \text { journal homepage: https://morphology-journal.com }\end{gathered}$

\title{
Peculiarities of gynecological history and reproductive status of women with psycho-emotional disorders related to prenatal stress
}

Semenenko I.V.

Zaporizhzhya State Medical University, Zaporizhzhya, Ukraine

\author{
ARTICLE INFO \\ Received: 19 July 2021 \\ Accepted: 19 August 2021 \\ UDC: $618.3-06: 159.542]-071.1$

\section{CORRESPONDING AUTHOR} \\ e-mail: ilonasemenenko13@gmail.com \\ Semenenko I.V.
}

\begin{abstract}
Persistent anovulation, menstrual disorders lead to the development of endocrinedependent gynecological diseases, one of the manifestations of which is primary infertility. The aim of the study: to assess the clinical features of history and reproductive status in women with psycho-emotional disorders associated with prenatal stress. The study involved 120 patients, 80 of whom suffered prenatal stress: 1 - the main group, which is divided into $1 A$ subgroup - women who underwent in vitro fertilization, and $1 B$ subgroup - women who did not undergo in vitro fertilization. For comparison, a 2 - control group of 40 women without prenatal stress with exclusively tubal factor of infertility, in which the parameters of the functional state of the reproductive system corresponded to the normal ovarian reserve. The age of patients ranged from 22 to 45 years. Complaints, anamnesis of disease and life, gynecological anamnesis, level of education were studied in all patients, the causes of infertility were assessed. The results of the study were processed using the statistical package of the licensed program "STATISTICA® for Windows 13.0". The normality of the distribution of indicators was established by the Shapiro-Wilk criterion. Descriptive statistics are presented as the arithmetic mean and standard deviation of $M \pm S D$ or the median and quartile interval Me (Q1-Q2) depending on the distribution of the trait. It was found that in place of residence, social status, the presence of bad habits, gynecological history of infertile patients in in vitro fertilization programs do not differ from healthy women with tubal-peritoneal factor infertility. There was a significant difference between the indicators of the nature of the menstrual cycle in the comparison groups. It has been found that a menstrual cycle of less than 23 days is a predictor of reduced functional activity of the hypothalamic-pituitary-ovarian axis in women. Analysis of hormonal regulation of reproductive function of the examined groups of women found the prevalence of FSH in the main group over the control $(9,611 \pm 0,212 \mathrm{vs}$. $6,221 \pm 0,113 \mathrm{mMod} / \mathrm{ml}$, respectively, $(p<0.05)$, and the level of TSH was not differences between comparison groups. We proposed to identify 3 states of ovarian reserve normal, low and extremely low for women with a history of infertility and prenatal stress. Conclusion: timely comprehensive assessment of the endocrine system, ovarian status in relation to the state of regulatory mechanisms of psychoemotional adaptation of women with infertility associated with prenatal stress, which we studied, requires a partial revision of approaches to this group of patients and timely use of in vitro extracorporeal the effectiveness of infertility treatment.

Keywords: infertility, prenatal stress, ovarian reserve, in vitro fertilization.
\end{abstract}

\section{Introduction}

Acting along with the mechanisms of excitation of the central and peripheral nervous system, the hypothalamicpituitary-adrenal system (HPAS) is involved in ensuring the adaptive response of the body to stress. The whole system is activated during stress, resulting in a clinic of stress syndrome $[3,5,10]$. Under stress, the central nervous system (CNS) undergoes changes that help prolong life.
At the same time, there is a mobilization of behavioral functions and reactions that help the body adapt more quickly to adverse conditions. Behavioral reactions and functions that ensure reproduction, nutrition and growth of the body during this period are suppressed $[4,7,12,14]$.

The main regulators of HPAS activity are corticotropinreleasing hormone $(\mathrm{CRH})$ and arginine-vasopressin [1, 
11], which have a synergistic stimulating effect on the secretion of adrenocorticotropic hormone (ACTH), increasing the secretion of cortisol in the adrenal cortex. Noradrenergic neurons in the brain stem have reciprocal connections with small neurosecretory cells of the hypothalamus and neurons of the paraventricular nucleus that secrete $\mathrm{ADH}[2,8]$. Decreased activity of the female reproductive system under stress is due to the activation of HPAS: 1) $\mathrm{CRH}$ and endorphin inhibit the secretion of gonadotropin-releasing hormone (GTRG) in the hypothalamus; 2) cortisol inhibits the secretion of GTRG in the hypothalamus, luteinizing hormone (LH) in the pituitary gland and estradiol (E2) in the ovaries; 3) cortisol reduces tissue sensitivity to estradiol $[2,15]$. Activation of the nervous system stimulates the reproductive system, while the effect of HPAS is stronger. However, activation of hypothalamic neurons that secrete $\mathrm{CRH}$ may increase the reproductive system's resistance to the inhibitory effect of HPAS. The reproductive system with the help of estradiol has a positive reverse effect on the links of the stress system, stimulating the secretion of $\mathrm{CRH}$.

Menstrual disorders are manifested by hypothalamicpituitary-ovarian failure and related changes during ovulation [3, 6, 19]. The development of endocrinedependent pathological conditions is caused by: lack of adequate correction of menstrual disorders and persistent anovulation. One of the manifestations of such pathological conditions is primary infertility $[3,6,10,13]$. Clinically, the most difficult are patients with infertility and regular menstruation $[4,6,8,20]$. The role of endocrine-dependent diseases as causes of infertility in women with a preserved menstrual cycle is still a matter of discussion [7, 8, 17]. Of particular note is the group of patients with elevated levels of blood prolactin (38\% of patients with endocrine forms of infertility) [9]. It should be noted that $12-45 \%$ of women with infertility and increased prolactin secretion have functional hyperprolactinemia, which is not associated with the presence of tumors $[2,13]$. In patients with normal prolactin levels, frequent factors of endocrine infertility are polycystic ovary syndrome, hyperandrogenism, dysfunction of the hypothalamic-pituitary system. Given the data of various authors, endocrine infertility is $32-40 \%$, successful treatment $-60-70 \%$ [2]. Endocrine infertility is $32-45 \%$, according to Ukrainian scientists $[5,16]$ in $40-42 \%$ of infertile women there is a violation of ovulation.

Anthropogenic factors in modern conditions cause the influence of altered psycho-emotional state of mothers as a risk factor for pathological abnormalities in the offspring $[7,17]$. Psychotraumatic effects can lead to acute stress and depressive disorders, in the presence of which women at different stages of pregnancy and breastfeeding can have an adverse effect on the child [4, 11], which determines the need to study this problem and develop methods to prevent possible disorders in offspring.

Stress experienced by mothers during pregnancy causes abnormalities in many physiological functions, disrupts the interaction between the immune, hormonal and mediator systems in children. This is confirmed by modern research. The mother's condition at the stage of pregnancy planning can also negatively affect the development of future offspring, as indicated by some scientific papers [7, 10,18]. However, comparative data on the impact of maternal psychogenic trauma during pregnancy or before conception on the formation of offspring in the literature are very few. However, such data appear to be important for the prediction, development and development of methods for correcting prenatal stress.

Almost all researchers recognize the influence of psychological state on the outcome of treatment $[1,10]$. Age and duration of marriage can affect the severity of stress [6]. In most women, after the detection of infertility, the feeling of depression reaches a maximum at 3 years, and at 4 years begins to adapt to infertility. Women diagnosed with idiopathic infertility are more optimistic than patients whose infertility is due to diseases that require surgical treatment [8].

The purpose of the study: to assess the clinical features of history and reproductive status in women with psychoemotional disorders associated with prenatal stress.

\section{Materials and methods}

The study was conducted on the basis of the Department of Reproductive Health of the municipal nonprofit enterprise "Regional Medical Center for Human Reproduction" Zaporizhzhya Regional Council, which involved 120 patients, 80 of whom suffered prenatal stress: 1 - main group, which was divided into: 1A subgroup women, who underwent in vitro fertilization (IVF), subgroup 1B - women who did not perform IVF. For comparison, a control group of 40 women without prenatal stress with exclusively tubal infertility factor was formed. In such women, the characteristics of the functional state of the reproductive system corresponded to the normal ovarian reserve [2, 7]. Exclusion criteria from the study were: patients with acute inflammatory, autoimmune, cancer and mental illness; with decompensated stage of somatic pathology.

Each patient was previously issued a questionnaire, which the patient completed only after obtaining consent to participate in the study. In the clinical study of patients studied complaints, medical history and life, gynecological history, level of education, assessed the causes of infertility. Prenatal stress was considered to be the presence in women during pregnancy of patients who subsequently developed infertility, symptoms of severe preeclampsia and/or the birth of children from this pregnancy with signs of intrauterine growth retardation.

The results of the study were processed using the statistical package of the licensed program "STATISTICA $\circledast$ for Windows 13.0". The normality of the distribution of indicators was established by the Shapiro-Wilk test. Descriptive statistics are presented as the arithmetic mean 
and standard deviation of $\mathrm{M} \pm \mathrm{SD}$, or the median and quartile interval Me (Q1-Q2) depending on the distribution of the trait. The comparisons of the three unrelated samples were performed according to the Mann-Whitney test. Comparisons of the three related samples were performed followed by pairwise comparison of groups using the nonparametric Wilkinson T-test.

\section{Results}

The mean age of patients was $27.92 \pm 1.04$ years $(28.32 \pm 1.31$ years in the main and $27.64 \pm 1.88$ years in the control group $(p>0.05))$. In analyzing the age structure of women who applied for diagnosis and treatment of infertility, we registered a significant percentage of patients over 35 years of age. We studied marital status, education, the state of the reproductive system, the parity of the surveyed women.

Among the women surveyed, $69 \%$ were urban residents and $31 \%$ were rural residents. Most women worked (82\%), $18 \%$ were housewives, and single persons were students. The social status of the studied patients is presented as follows: in $1 \mathrm{~A}$ subgroup employees were 28 women $(70 \%)$, workers - $6(15 \%)$, housewives - $3(8 \%)$, students - $3(8 \%)$, in $1 \mathrm{~B}$ subgroup and control group respectively, employees were 27 and 11 women (68\% and $28 \%$ ), workers - 6 and 10 women (15\% and 25\%), housewives - 4 and 16 patients $(10 \%$ and $40 \%)$, students - 3 women in each group (8\%). $52 \%$ of the employees were patients with higher education, $25 \%$ of them were business owners, executive and financial directors, accountants, $16 \%$ were doctors, nurses, laboratory assistants, teachers, methodologists and educators. Scientists accounted for a smaller percentage - $16 \%$. In terms of social status, the distribution in all the groups we studied was homogeneous. A significant difference between these indicators of clinical groups was not detected ( $p>0.05)$. No occupational hazards were detected. Among patients of subgroup 1A, 22 women smoked tobacco (48\%), subgroup 1B smoked 25 (47\%). Among patients in the control group - 19 (53\%) ( $p>0.05)$. Accordingly, the average number of cigarettes smoked per day was: $5,761 \pm 0,542 ; 5.371 \pm 0.362$ and $5.422 \pm 0.321$. Thus, the study groups were homogeneous in terms of the number of women who smoked and the intensity of cigarette smoking.

The table 1 show the characteristics of the menstrual cycle in the examined women, the nature of menstruation. Analysis of menstrual function showed no differences between patients in the main and control groups by age of menarche $(12.27 \pm 0.07$ in subgroup $1 \mathrm{~A}$ and $12.38 \pm 0.15$ in subgroup $1 \mathrm{~B}$ versus $12.28 \pm 0.13$ years in the control group), by the average duration of the menstrual cycle $(27.18 \pm 0.16$ and $27.14 \pm 0.19$ vs. $27.27 \pm 0.21$ days), by the average number of menstrual cycles per year $(12.14 \pm 0.12$ and $12.17 \pm 0.11$ vs. $12.14 \pm 0.18)$. The longer duration of menstrual bleeding compared with the control was observed among patients of the main group (5.381 \pm 0.212 days) in subgroup $1 \mathrm{~A} 1.10$ times $(5.941 \pm 0.121$ days, $\mathrm{p}<0.03)$ and in subgroup $1 \mathrm{~B}-1.19$ times $(6,142 \pm 0.121$ days, $\mathrm{p}<0.01$ ).

When studying the nature of menstrual function, it was found that most women had a regular menstrual cycle lasting from 23 to 33 days. Menstrual cycles lasting less than 23 days were found in most women of subgroups $1 \mathrm{~A}$ and $1 \mathrm{~B}$, oligomenorrhea and metrorrhagia were observed in the same patients. At the same time, in patients of the control group, the menstrual cycle did not change. After receiving the results of the study, we concluded that a clinical sign such as a menstrual cycle lasting less than 23 days may be a symptom of reduced functional activity in women (Table 2).

The average age of onset of sexual life in subgroup $1 \mathrm{~A}$ was $19.18 \pm 0.22$ years, in $1 \mathrm{~B}-19.21 \pm 0.21$ against $18.94 \pm 0.44$ years in the control group. We examined 34 persons of subgroup $1 \mathrm{~A}(84 \%)$ and 35 persons of subgroup $1 \mathrm{~B}(86 \%)$, as well as 34 persons of the control group (84\%) were married and had a regular sexual life. Hormonal contraception was used by 16 (28\%), 7 (21\%) and 19 (38\%) women, respectively $(p>0.05)$. It was found that the distribution of the average age of onset of sexual life, the presence of regular sexual life in marriage, the use of combined oral contraceptives is evenly distributed in the main and control groups (Table 3).

The majority of women were in a registered marriage: $84 \%$ of marriages lasted more than 5 years, 1 marriage took place 3 months before the application, the longest marriage lasted 25 years. Among the women surveyed, $77 \%$ were remarried, $22 \%$ were in their first marriage. Among women who were remarried, $86 \%$ had healthy children from the previous one, and therefore, their motivation to apply to the reproduction center was the desire to have a child with the current husband.

The mean age of examination and treatment among patients with primary infertility was 12 years. Most patients first sought infertility treatment after 7-9 years of marriage,

Table 1. Characteristics of the menstrual cycle.

\begin{tabular}{|l|c|c|c|c|}
\hline \multicolumn{1}{|c|}{ Groups } & $\begin{array}{c}\text { The average age of onset } \\
\text { of menstruation }\end{array}$ & $\begin{array}{c}\text { Average duration of } \\
\text { menstruation, days }\end{array}$ & $\begin{array}{c}\text { The average duration of } \\
\text { the menstrual cycle, days }\end{array}$ & $\begin{array}{c}\text { The average number of } \\
\text { menstrual cycles per year }\end{array}$ \\
\hline 1A subgroup, $\mathrm{n}=40$ & $12.27 \pm 0.07^{\star}$ & $5.941 \pm 0.12^{* \star *}$ & $27.18 \pm 0.16$ & $12.14 \pm 0.12$ \\
\hline 1B subgroup, $\mathrm{n}=40$ & $12.38 \pm 0.15$ & $6.142 \pm 0.12^{* * *}$ & $27.14 \pm 0.19$ & $12.17 \pm 0.11$ \\
\hline Control group, $\mathrm{n}=40$ & $12.28 \pm 0.13$ & $5.381 \pm 0.21^{\star \star}$ & $27.27 \pm 0.21$ & $12.14 \pm 0.18$ \\
\hline
\end{tabular}

Notes: ${ }^{*}-p_{1-k}<0.05 ;{ }^{* *}-p_{2-k}<0.05 ;{ }^{* *}-p_{1-2}<0.05$. 
Table 2. Characteristics of the menstrual cycle in the examined women.

\begin{tabular}{|l|c|c|c|}
\hline & $\begin{array}{c}1 \mathrm{~A} \\
\text { subgroup, } \\
\mathrm{n}=40\end{array}$ & $\begin{array}{c}1 \mathrm{~B} \\
\text { subgroup, } \\
\mathrm{n}=40\end{array}$ & $\begin{array}{c}\text { Control } \\
\text { group, } \\
\mathrm{n}=40\end{array}$ \\
\hline Regular menstrual cycle & $24 \%$ & $18 \%$ & $96 \%$ \\
\hline Menstrual irregularities & $85 \%$ & $88 \%$ & $4 \%$ \\
\hline Short menstrual cycle & $72 \%$ & $96 \%$ & $0 \%$ \\
\hline Oligomenorrhea & $64 \%$ & $76 \%$ & $2 \%$ \\
\hline Metrorrhagia & $7 \%$ & $8 \%$ & $0 \%$ \\
\hline
\end{tabular}

Table 3. The nature of the sexual life of the examined patients.

\begin{tabular}{|c|c|c|c|}
\hline Groups & $\begin{array}{c}\text { The average age of } \\
\text { onset of sexual } \\
\text { activity, M } \pm \text { SE }\end{array}$ & $\begin{array}{c}\text { Regular sex in } \\
\text { marriage, } \mathrm{n}(\%)\end{array}$ & $\begin{array}{c}\text { Application of } \\
\text { COCP, } \mathrm{n}(\%)\end{array}$ \\
\hline $\begin{array}{c}1 \mathrm{~A} \text { subgroup, } \\
\mathrm{n}=40\end{array}$ & $19.18 \pm 0.22$ & $34(84)$ & $16(28)$ \\
\hline $\begin{array}{c}1 \mathrm{~B} \text { subgroup, } \\
\mathrm{n}=40\end{array}$ & $19.21 \pm 0.21$ & $35(86)$ & $7(21)$ \\
\hline $\begin{array}{c}\text { Control group, } \\
\mathrm{n}=40\end{array}$ & $18.94 \pm 0.44$ & $34(84)$ & $19(38)$ \\
\hline
\end{tabular}

$40 \%$ of them used various methods of contraception in the first 3 years of marriage, $28 \%$ of women were recommended reconstructive plastic surgery on the fallopian tubes, $14 \%$ of men in couples underwent repeated infertility treatment courses. In particular, multiple courses of therapy for urogenital infections were conducted, the stages of examination and treatment were quite long, with the use of numerous hormonal drugs in the absence of evidence for their appointment.

The main complaint of all patients was the lack of the desired pregnancy. The duration of infertility was $5.331 \pm 0.422$ years. After collecting the anamnestic data (genealogical anamnesis, transferred childhood infections, etc.) no deviations from the population norm were revealed. Somatic health was also determined. The somatic anamnesis of the studied women was represented by the following diseases: diseases of the cardiovascular system occurred in 37 women - 31\%, neuro-circulatory dystonia by hypertensive type - in 7 women (6\%), hypertension - in 30 patients $(25 \%)$, disease of respiratory system - in 9 women, which was $8 \%$, chronic tonsillitis - in 7 patients $(5.5 \%)$, chronic bronchitis - in $2(1.5 \%)$, pneumonia - in 1 woman $(1 \%)$, diseases of the digestive system - in 49 women (41\%), biliary tract diseases - in 7 women $(6 \%)$, chronic gastritis - in 8 women (7\%), chronic cholecystitis - in 10 women $(9 \%)$, gastric ulcer - in 1 patient $(1 \%)$, chronic pancreatitis - in 10 women $(9 \%)$, gallstone disease - in 10 women $(9 \%)$, urinary tract disease - in 5 women $(4.5 \%)$, chronic pyelonephritis - in 3 women (3\%), chronic cystitis in 2 women, which amounted to $1.5 \%$, varicose veins of the lower extremities - in 3 patients (3\%). However, these conditions were compensated and were not a contraindication to planning and carrying a pregnancy.

Among the examined patients' parity was studied: in $5 \%$ - preterm birth, in $36 \%$ - preterm birth and artificial abortion, $25 \%$ of patients had a history of preterm birth and miscarriage, 15\% - miscarriage, artificial abortion, 7\% ectopic pregnancy, $11 \%$ - artificial abortions (Fig. 1).

The analysis of the reproductive function of patients revealed that $46 \%$ of patients had primary infertility and $54 \%$ had secondary infertility. When analyzing the causes of infertility in women with prenatal stress, only a small proportion of patients revealed monofactorial causes: $48 \%$ had a combination of two or more factors of reproductive dysfunction, $13 \%$ - idiopathic infertility. Chronic endometritis (9.8\%), cylindrical epithelial ectopia (29\%), uterine and/or ovarian endometriosis $(17 \%)$, chronic salpingitis and oophoritis were found in $47 \%$ of gynecological patients.

In $30 \%$ of women $(n=36)$ gynecological operations were performed according to the indications: laparotomy in 14 patients (11\%), laparoscopy - in 24 patients (20\%), 1 hysteroscopy - in 120 patients (100\%), 2 hysteroscopies in 33 women (28\%), 3 hysteroscopies - in 17 patients (14\%), total surgical interventions - 208. Diagnostic hysteroscopy with mandatory determination of markers of chronic endometritis in the biopsy was performed in all patients 23 cycles before embryo transfer. From the anamnesis, 76\% of women underwent hysteroscopy or medical-diagnostic scraping of the uterine mucosa and cervical canal. Such procedures were performed for endometrial polyps in every second or third case. All previous diagnoses were confirmed histologically.

The concentration of basic hormones in the serum of the examined groups of women was determined. Folliclestimulating hormone (FSH) in subgroup $1 \mathrm{~A}$ was 9.034 $0.213 \mathrm{mlU} / \mathrm{ml}$, in subgroup $1 \mathrm{~B} 10.51 \pm 0.62 \mathrm{mIU} / \mathrm{ml}$, against $6.207 \pm 0.411 \mathrm{mlU} / \mathrm{ml}$ in the control group. LH in subgroup $1 \mathrm{~A}$ was $8.731 \pm 0.401 \mathrm{mIU} / \mathrm{ml}$, in subgroup $1 \mathrm{~B}-9.231 \pm$ $0.303 \mathrm{mIU} / \mathrm{ml}$, against $5.521 \pm 0.411 \mathrm{mlU} / \mathrm{ml}$ in the control group. The level of estradiol in subgroup $1 \mathrm{~A}$ was $39.04 \pm 5.31$ $\mathrm{pg} / \mathrm{ml}$, in subgroup $1 \mathrm{~B}-37.21 \pm 4.22 \mathrm{pg} / \mathrm{ml}$, against $3.112 \pm 3.213 \mathrm{pg} / \mathrm{ml}$ in the control group. The level of free testosterone in the $1 \mathrm{~A}$ subgroup was $0.721 \pm 0.022 \mathrm{pg} / \mathrm{ml}$, in the $1 \mathrm{~B}$ subgroup $-0.641 \pm 0.032 \mathrm{pg} / \mathrm{ml}$, against $0.542 \pm$ $0.211 \mathrm{pg} / \mathrm{ml}$ in the control group. The level of thyroid-

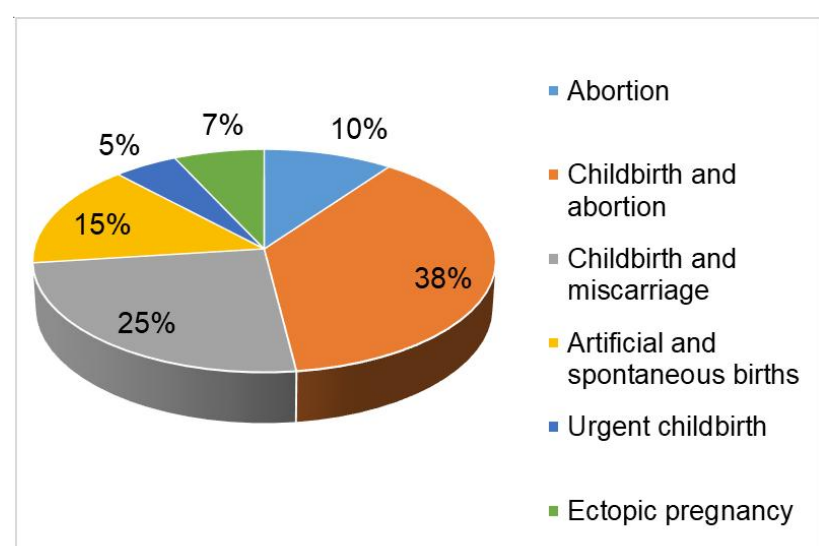

Fig. 1. Results of previous pregnancies of surveyed women. 
stimulating hormone in subgroup $1 \mathrm{~A}$ was $0.921 \pm 0.421 \mu \mathrm{lU} /$ $\mathrm{ml}$, versus $0.651 \pm 0.092 \mu \mathrm{lU} / \mathrm{ml}$ and $1.003 \pm 0.511 \mu \mathrm{lU} / \mathrm{ml}$ in subgroup $1 \mathrm{~B}$ and control group, respectively. The level of progesterone in subgroup $1 \mathrm{~A}$ was $0.631 \pm 0.312 \mathrm{nmol} / \mathrm{l}$, in subgroup $1 \mathrm{~B}-0.761 \pm 0.213 \mathrm{nmol} / \mathrm{l}$, against $0.652 \pm$ $0.231 \mathrm{nmol} / \mathrm{in}$ the control group. When analyzing the average indicators of the concentration of hormones in the blood of the examined women, it was found that the indicators of $\mathrm{FSH}$ are higher in the main group $(\mathrm{p}<0.05)$. The level of TSH did not differ between the comparison groups. In the main group of women studied, the concentration of antimullerian hormone (AMP) in the blood for 2-5 days of the menstrual cycle was below normal, the concentration of total testosterone - within normal limits. In the control group, the AMP was within normal limits $(3.321 \pm 0.221 \mathrm{ng} / \mathrm{ml})$.

The ovarian reserve (OR) of women was assessed by the following indicators: the level of AMP, FSH, the number of antral follicles (NAF) in both ovaries in total and the volume of the ovaries. In the women who participated in the study, OR was found: $\mathrm{AMH}-1.4 \mathrm{ng} / \mathrm{ml}$ in the main group, $3.3 \mathrm{ng} / \mathrm{ml}$ in the control group $(p<0.01)$. FSH $-9.6 \mathrm{mIU} / \mathrm{ml}$ in the main group, and $6.2 \mathrm{mIU} / \mathrm{ml}$ in the control group $(p<0.1)$. NAF in both ovaries, respectively, was $4.106 \pm 0.202$ in the main and $12.41 \pm 0.10$ antral follicles in the control groups. The average ovarian volume was determined by ultrasound, it was: $6.101 \pm 0.224 \mathrm{~cm}^{3}$ in the main and $9.601 \pm 0.221 \mathrm{~cm}^{3}$ in the control groups. Thus, unchanged ovarian reserve was determined in women of the control group. According to the above indicators of OR, we proposed to identify 3 states of OR - normal, low and extremely low for women with a history of infertility and prenatal stress. Normal ovarian reserve was determined as follows with the following parameters: 1): regular menstrual cycle on average 28-30 days, FSH less than $10 \mathrm{mIU} / \mathrm{ml}$; AMH level greater than $1.0 \mathrm{ng} / \mathrm{ml}$; ovarian volume not less than $5 \mathrm{~cm}^{3}$, NAF - not less than 10 in both ovaries; 2) reduced OR: menstrual cycle lasting 21-23 days; $\mathrm{FSH}$ level $>15 \mathrm{mIU} / \mathrm{ml}$; AMH level $<1.0 \mathrm{ng} / \mathrm{ml}$; ovarian volume from 3 to $5 \mathrm{~cm}^{3}$; NAF no more than 6 pieces in both ovaries; 3) extremely low OR: menstrual irregularities on the background of prenatal stress; increasing the level of FSH $>15 \mathrm{mlU} / \mathrm{ml}$; AMH level less than $0.01 \mathrm{ng} / \mathrm{ml}$; ovarian volume $<3 \mathrm{~cm}^{3}$; NAF - no more than 4 pieces in both ovaries.

\section{Discussion}

According to the results of our study, it was found that the place of residence, social status, the presence of bad habits, gynecological history of patients with infertility in IVF programs do not differ from healthy women with tubalperitoneal infertility $[1,3,24,26]$. Similar data are reflected in scientific papers, which provide evidence of the frequency of infertility, the percentage between primary and secondary infertility, the frequency of pregnancy after IVF [4, 9, 10, 22]. There was a significant difference between the indicators of the nature of the menstrual cycle in the comparison groups, such as: the duration of the menstrual cycle, the average age of menstruation, the average duration of menstruation, the average duration of the menstrual cycle, the average number of menstrual cycles per year. We found that a menstrual cycle lasting less than 23 days is a predictor of reduced functional activity of the hypothalamicpituitary-ovarian axis in women. These data are consonant with the works of A.V. Kaminsky [7], where it is shown that the stress experienced by patients affects the regulation of hypothalamic-pituitary-ovarian relations, and in the long run on food and coping behavior, lipid and carbohydrate metabolism.

Analysis of hormonal regulation of reproductive function of the examined groups of women found the prevalence of $\mathrm{FSH}$ in the main group over the control $(9.611 \pm 0.212$ vs. $6.221 \pm 0.113 \mathrm{mlU} / \mathrm{ml}$, respectively, $p<0.1)$, and the level of TSH had no differences between the studied groups. In the main group of women studied, the concentration of $\mathrm{AMH}$ is below normal (according to normal laboratory reference values - 1.0-2.5 $\mathrm{ng} / \mathrm{ml}$ ), ie less than $1.0 \mathrm{ng} / \mathrm{ml}$, compared with the control group $(p<0.1)$, the concentration of total testosterone is within normal limits, while in the control group the average value of $\mathrm{AMH}$ was equal to $3,321 \pm 0,221 \mathrm{ng} / \mathrm{ml}$. According to these indicators of OR, we proposed to identify 3 states of OR - normal, low and extremely low for women with a history of infertility and prenatal stress. The basis for this distribution were the results of previous studies by various authors [13, 15, 21, 23], but for the first time we detailed the criteria for determining OR for a group of women with infertility and history of prenatal stress. An important result of the study is the fact that in most patients with a history of infertility and prenatal stress, who were treated with IVF, there is a decrease in OR. These data were the basis for the development of treatment tactics and recommendations of this group of women on the feasibility and timely use of IVF programs [13, 25]. Similar data are given by T.F. Tatarchuk and co-authors [8]. We were unable to compare the features of the anamnesis, the state of neuroendocrine regulation of women with infertility and prenatal stress in the anamnesis with other literature data due to the lack of publications on this topic.

The identified features of gynecological history and reproductive status of women with psychoemotional disorders associated with prenatal stress will allow obstetricians and gynecologists to further analyze the state of the reproductive system, thereby increasing the frequency of natural fertility cycles and the effectiveness of fertilization in IVF programs.

\section{Conclusions}

1. One of the clinical signs of violation of regulatory relationships in the hypothalamic-pituitary regulation of reproductive function in women with infertility and prenatal stress in the anamnesis can be considered the duration of the menstrual cycle less than 23 days.

2. In women with infertility and prenatal stress while maintaining the optimal size of the ovaries there is a 
decrease in OR in the form of an increase in the concentration of FSH more than $15 \mathrm{mIU} / \mathrm{ml}(p<0.01)$ and a decrease in $\mathrm{AMH}$ less than $1.0 \mathrm{ng} / \mathrm{ml}(\mathrm{p}<0.01)$, as well as reducing the number of antral follicles to 6 pieces in both ovaries.

3. Timely comprehensive assessment of the endocrine

\section{References}

[1] Bobrov, A.E. (2017). Проблема психосоматических соотношений и некоторые методологические вопросы психопатологии [The problem of psychosomatic relations and some methodological issues of psychopathology]. Социальная и клиническая психиатрия - Social and Clinical Psychiatry, 27(1), 98-103.

[2] Dudina, O.O., \& Gaborets, Y.Y. (2017). Репродуктивне здоров'я як чинник фертильності жінок і якості здоров'я народжуваних поколінь [Reproductive health as a factor of women's fertility and quality of health of nascent generations]. Економіка і право охорони здоров'я - Economics and Law of Health Care, 6(2), 28-35.

[3] Zhylka, N.J., Myronjuk, I.S., \& Slabkyi, G.O. (2018). Характеристика деяких показників репродуктивного здоров'я жіночого населення України [Characteristics of Some Indicators of Reproductive Health of the Female Population of Ukraine]. Медичні новини - Wiadomosci Lekarskie, LXXI(9), 18031808.

[4] Zhuk S.I., \& Schurevskaya O.D. (2016). МикроРНК 210, 21 современные маркеры стресса у беременных [MicroRNA 210, 21 - modern stress marker in pregnant]. Репродуктивное здоровье. Восточная Европа - Reproductive Health. Eastern Europe, 5, 615-622.

[5] Kalinichenko, D.O. (2019). Кількісна оцінка репродуктивного потенціалу жінок раннього фертильного віку [Quantitative assessment of the reproductive potential of women of early fertile age]. Довкілля та здоров'я - Environment and Health, (3(92)), 11-16. https://doi.org/10.32402/dovkil2019.03.011

[6] Korolovich, O.V. (2018). Детермінанти психогенного безпліддя: глибинний погляд на проблему [Determinants of psychogenic infertility: an in-depth look at the problem]. Псuхологічний журнал - Psychological Journal, 4(8), 18, 76-85. https://doi.org/10.31108/1.2018.8.18.5

[7] Kaminsky, A.V. (2018). Біоелектрична активність кори головного мозку у пацієнтів з циклами допоміжних репродуктивних технологій [Bioelectric activity of cerebral cortex in patients with cycles of assisted reproductive technologies]. Журнал освіти, здоров'я та спорту - Journal of Education, Health and Sport, 8(7), 445-452. doi: http://dx.doi.org/10.5281/ zenodo. 1332526

[8] Tatarchuk, T.F. (2013). Ефективність застосування препаратів, що надають дофраминергическу дію, в комплексній терапії дисгормональної стрес-індукованої патології [The effectiveness of drugs that have dopaminergic action in the treatment of dyshormonal stress-induced pathology]. Репродуктивна ендокринологія - Reproductive endocrinology, 3, 90-94.

[9] Shevchuk, P.E. (2015). Реконструкція структури народжених за черговістю народження та віком матері [Reconstruction of the structure of births according to the order of birth and mother's age]. Демографія та соціальна економіка - Demography and Social Economy, 23(1), 113125.

[10] Bennett, L.R., \& de Kok, B. (2018). Reproductive Desires and system, ovarian status in relation to the state of regulatory mechanisms of psychoemotional adaptation of women with infertility associated with prenatal stress, which we studied, requires a partial review of approaches to this group of women and timely use of IVF to improve performance infertility treatment.

Disappointment. Medical Anthropology, 37(2), 91-100. doi: 10.1080/01459740.2017.1416609

[11] Duhig, K., Chappell, L.C., \& Shennan, A.H. (2016). Oxidative stress in pregnancy and reproduction. Obstetric Medicine, 9(3), 113-116. https://doi.org/10.1177/1753495X16648495

[12] Elwenspoek, M.M.C., Kuehn, A., Muller, C.P., \& Turner, J.D. (2017). The effects of early life adversity on the immune system. Psychoneuroendocrinology, 82, 140-154. doi: 10.1016/j.psyneuen.2017.05.012

[13] Gareri, P., Castagna, A., Cotroneo, A.M., Putignano, S., De Sarro, G., \& Bruni, A.C. (2015). The role of citicoline in cognitive impairment: pharmacological characteristics, possible advantages, and doubts for an old drug with new perspectives. Clin. Interv. Aging, 10, 1421-1429. doi: 10.2147/ CIA.S87886

[14] Gruzieva, T.S., Diachuk, M.D., Inshakova, H.V., \& Zamkevych, V.B. (2019). Modern Demographic Trends in Ukraine as a Ground for Realization of Prevention Strategies. Wiadomosci Lekarskie, 72(10), 2033-2039. PMID: 31983148

[15] Hryshchenko, M.H., Luts'kyy, A.S., \& Parashchuk, V.Y. (2017). Оцінка ефективності екстракорпорального запліднення після перенесення вітрифікованих бластоцист у природному циклі та із застосуванням замісної гормональної терапії [Evaluation of the effectiveness of in vitro fertilization after the transfer of vitrified blastocysts in the natural cycle and with the use of hormone replacement therapy]. Міжнародний медичний журнал - International Medical Journal, 23(4), $42-46$.

[16] Lee, Y., Oh, J.S., Chung, S.J., Lee, J.J., Chung, S.J., Moon, H. ... Sohn, Y.H. (2018). The presence of depression in de novo Parkinson's disease reflects poor motor compensation. PLOS ONE. 13(9). 1-10. https://doi.org/10.1371/ journal.pone.0203303

[17] Li, Y.H., \& Marren, A. (2018). Recurrent Pregnancy Loss: A Summary of International EvidenceBased Guidelines and Practice. Aust. J. Gen. Pract., 47(7), 432-436. doi: 10.31128/ AJGP-01-18-4459

[18] Lubinsky, M. (2018). Evolutionary Justifications for Human Reproductive Limitations. J. Assist. Reprod. Genet., 35(12), 2133-2139. doi: 10.1007/s10815-018-1285-3

[19] Malak, A.L.S.B., Vasconcellos, L.F., Pereira, J.S., Greca, D.V., Cruz, M., Alves, H.V.D. ... Charchat-Fichman, H. (2017). Symptoms of depression in patients with mild cognitive impairment in Parkinson's disease. Dement Neuropsychol., 11(2), 145-153. doi: 10.1590/1980-57642016dn11-020007

[20] Nicoloro-Santa, B.J.M., Lobel, M., Bocca, S., Stelling, J.R., \& Pastore, L.M. (2017). Psychological and emotional concomitants of infertility diagnosis in women with diminished ovarian reserve or anatomical cause of infertility. Fertil. Steril., 108(1), 161-167. doi: 10.1016/j.fertnstert.2017.05.008

[21] Panico, A., Messina, G., Lupoli, G.A., Lupoli, R., Cacciapuoti, M., Moscatelli, F. ... Lupoli, G. (2017). Quality of life in overweight (obese) andnormal - weight women with polycystic ovary syndrome. Patient Prefer Adherence, 11, 423-429. doi: 


\subsection{7/PPA.S119180}

[22] Pinar, M.H., Gibbins, K., He, M., Kostadinov, S., \& Silver, R. (2018). Early Pregnancy Losses: Review of Nomenclature, Histopathology, and Possible Etiologies. Fetal Pediatric Pathology 37(3), 191-209. doi: 10.1080/ 15513815.2018.1455775

[23] Plana-Ripoll, O., Li, J., Kesmodel, U.S., Olsen, J., Parner, E., \& Basso, O. (2016). Maternal stress before and during pregnancy and subsequent infertility in daughters: a nationwide population-based cohort study. Hum. Reprod., 31(2), 454-462. doi: 10.1093/humrep/dev309
[24] Simmons, A.D. (2018). Parkinson's Disease. In: D. Rakel (Ed.), Integrative Medicine (Fourth Edition). Philadelphia, PA: Elsevier.

[25] Skorvanek, M., Martinez-Martin, P., Kovacs, N., RodriguezViolante, M., Corvol, J., Taba, P. ... Stebbins, G.T. (2017). Differences in MDS-UPDRS Scores Based on Hoehn and Yahr Stage and Disease Duration. Movement Disorders Clinical Practice, 4(4), 536-544. doi: 10.1002/mdc3.12476

[26] Yusuf, L. (2016). Depression, anxiety and stress among female patients of infertility; a case control study. Pak. J. Med. Sci., 32(6), P.1340-1343. doi: 10.12669/pjms.326.10828

\section{ОСОБЛИВОСТІ ГІНЕКОЛОГІЧНОГО АНАМНЕЗУ ТА РЕПРОДУКТИВНОГО СТАТУСУ ЖІНОК ІЗ ПСИХОЕМОЦІЙНИМИ ПОРУШЕННЯМИ, ПОВ'ЯЗАНИМИ 3 ПЕРЕНЕСЕНИМ ПРЕНАТАЛЬНИМ СТРЕСОМ}

Семененко І.В.

Стійка ановуляція, порушення менструального циклу призводять до розвитку ендокринозалежних патологічних станів. Первинна неплідність є проявом таких гінекологічних захворювань. Мета дослідження: провести оцінку клінічних особливостей анамнезу та репродуктивного статусу у жінок із психоемоційними порушеннями, пов'язаними з перенесеним пренатальним стресом. У дослідженні взяли участь 120 пацієнток, 80 з яких перенесли пренатальний стрес: 1 - основна група, яка розподілена відповідно на 1А підгрупу - жінки, котрим проводили екстракорпоральне запліднення, та 1Б підгрупу - жінки, котрим екстракорпоральне запліднення не проводили. Для порівняння сформовано 2 - контрольну групу із 40 жінок без пренатального стреса з виключно трубним фрактором безпліддя. У иих жінок всі характеристики репродуктивного статусу відповідали нормальному яєчниковому резерву. Вік пацієнток коливався від 22 до 45 років. У всіх пацієнток вивчали скарги, анамнез захворювання та життя, гінекологічний анамнез, рівень освіти, оцінювали причини безпліддя. Результати дослідження оброблені із застосуванням статистичного пакету ліцензійної програми "STATISTICA® for Windows 13.0". Нормальність розподілу показників встановлювали за критерієм Шапіро-Уілка. Дані описової статистики подано у вигляді середнього арифметичного та стандартного відхилення $M \pm S D$ або медіани та міжквартильного інтервалу Ме (Q1-Q2) залежно від розподілу ознаки. Встановлено, що за місцем проживання, соціальним статусом, наявністю шкідливих звичок, даними гінекологічного анамнезу безплідні пацієнтки в програмах екстракорпорального запліднення не відрізняються від здорових жінок із трубно-перітонеальним фрактором безпліддя. Виявлено достовірну відмінність між показниками характеру менструального циклу у групах, що порівнювали. З'ясовано, що менструальний цикл тривалістю менше 23 днів $є$ предиктором зниженої функціональної активності гіпоталамо-гіпофрізарно-яєчникової вісі у жінок. Аналіз гормональної регуляції репродуктивної функції обстежених груп жінок встановив превалювання показників фолікулостимулюючого гормону в основній

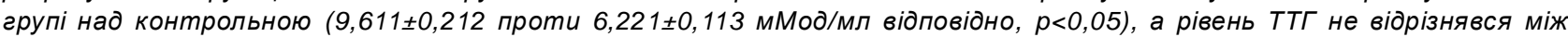
досліджуваними групами. Нами запропоновано для жінок з безпліддям та перенесеним пренатальним стресом в анамнезі виділити 3 стани яєчникового резерву, а саме: нормальний, низький та вкрай низький. Таким чином, своєчасна комплексна оцінка стану ендокринної системи, стану яєчників у взаємозв'язку зі станом регуляторних механізмів психоемоційної адаптації жінок з безпліддям, асоційованим з пренатальним стресом, яка була нами досліджена, вимагає часткового перегляду підходів до цієї групи пацієнток та своєчасного застосування екстракорпорального запліднення для покращення результативності лікування безпліддя.

Ключові слова: безпліддя, пренатальний стрес, оваріальний резерв, екстракорпоральне запліднення. 